\title{
Workplace Violence (Mobbing) the Example of A Hospital in Greece during the Economic Crisis
}

Chrysi Papadeli ${ }^{1}$, Adamantia Filippou ${ }^{2}$, Ioannis Haidemenos ${ }^{3}$, Eydoksia Tsilakidou ${ }^{4}$, Agisilaos Krachtis ${ }^{5}$, Chaidemenos Ioannis $^{6}$, Tselekidou Evdoxia ${ }^{7}$

${ }^{1}$ School of Dentistry, Faculty of Health Sciences, Aristotle University of Thessaloniki. Thessaloniki, Greece,

${ }^{2}$ General Dentist, Aristotle University of Thessaloniki

${ }^{3}$ Register nurse, Msc, theater nurse, Saint Dimitrios Hospital

Thessaloniki, Greece

${ }^{4}$ Register nurse, ICU, Saint Dimitrios Hospital

Thessaloniki, Greece

${ }^{5}$ General Doctor, Aristotle University of Thessaloniki.

Thessaloniki, Greece

${ }^{6}$ Register nurse, Msc, theater nurse, Saint Dimitrios Hospital

Thessaloniki, Greece

${ }^{7}$ Register nurse, ICU, Saint Dimitrios Hospital

Thessaloniki, Greece

*Corresponding author's email: chrysapapadeli [AT] gmail.com

\begin{abstract}
----
Aim: During the last decade various efforts have been made to investigate and record the "mobbing syndrome" in Greece. The present study aims to map the rates of mobbing, to determine the causes, to highlight the vulnerable groups to mobbing, to describe its expression, and to document the ways of dealing with it.

Material and method: The study used the LIPT (Leymann Inventory of Psychological Terrorization) questionnaire, which has been widely used to measure mobbing. The SPSS statistical program was used for statistical analysis and processing of the results.

Results: Out of a total of 150 questionnaires, 91 were returned correctly completed. The majority of the participants were women, mainly aged 41-45 years, graduates of universities/universities of applied sciences, married, with more than 21 years of experience. The mobbing rate recorded was $16.48 \%$. The most frequent mobbing behavior is the statement " they often talk behind your back" 31.9\%, at least once a month $30 \%$ and $79 \%$ still experience mobbing behaviors to date. Mobbing of others has been observed in 45.1\%. Mobbing comes from someone higher up the hierarchy in $34.1 \%$ and is attributed to the poor organization in $27.5 \%$ and management problems in $34.1 \%$. To deal with the phenomenon they primarily turned to colleagues $29.7 \%$.

Conclusions: This study was an attempt to investigate and document the "mobbing syndrome" among nurses in a public hospital. The results demonstrate that mobbing behaviors are practiced in the workplace and experienced by about half of the survey population and a large proportion still experience them today.
\end{abstract}

Keyword--- Ethical and psychological harassment, Mobbing, Workplace harassment, LIPT Questionnaire

\section{INTRODUCTION}

Work-related psychological violence can be defined as a situation in which a person is subjected to hostile behavior by one or more people in his or her work environment who constantly and repeatedly try to hurt, oppress, abuse, or exclude him or her for a long period, or even drive him or her away (Leymann H,1996) 
The "mobbing syndrome" was first studied by Leymann in the 1990s. (Leymann H. 1990) Based on Leymann bullying is "the systematic and sustained psychological attack that employees in the work environment receive from hierarchical superiors or colleagues. Aggressive behaviors are aimed at humiliating the victim, damaging his or her dignity and can lead to isolation from the workplace"

The negative experiences caused by "mobbing" do not only concern the victim, but also affect his/her family (Duffy M, Sperry L. 2007) and work environment

Mobbing syndrome hurts the productivity and efficiency of the organization. ( Chappell D\& Di Martino V. 2001).

\section{Mobbing has been attributed to other definitions of the phenomenon:}

- "Bullying" (Olweus 1993;)

- "Psychological terror" (Leymann, 1996)

- $\quad$ Harassment (Brodsky, 1976)

- "Work Harassment" (Zapf D. and Gross C.,2001,)

- 'Harcèlement Moral' (Hirigoyen 2009,2012)

- $\quad$ "Emotional abuse" (Keashly \& Jagatic 2003)

- "Scapegoating (Vartia M. (1993,2003)

- 'Workplace incivility' (Andersson 2001)

- 'Abusive Supervision' (Tepper, 2000)

- 'Victimization' (Aquino 2000, Aquino K. and Thau S. 2009, Notelaers 2010)

\section{Directions of Mobbing}

Vertical or Downward: Harassment that comes from the supervisor to the subordinate and is the most common form of psychological harassment. It involves the form of abuse of authority (Ferrari 2004).

Horizontal: Harassment between colleagues of the same rank. . (Hirigoyen 2009, Ferrari 2004).

Ascending: It occurs, not often, in cases where there is no recognition in the person of the superior, by one or more people in the team (Khoo, 2010).

"Strategic" or "corporate" mobbing. It is a policy of some organizations when they want to push people in their workforce to resign

Double mobbing. The role of family and friends is changed from supportive to pushy and critical. (Ege, 2007)

Ways of expressing Mobbing( Sahin B.et al 2012)

- Behaviors that prohibit expression and communication about working relationships (constant negative criticism)

- Behaviors that offend social relationships (isolation)

- Behaviors that offend work practice/professional status (constantly new tasks, humiliating tasks, etc.)

- Behaviors that damage personal and professional reputation (false rumors, ridicule, mental destabilization) 


\begin{tabular}{|c|c|}
\hline Role & Contributions \\
\hline Victim & $\begin{array}{l}\text { - Diversity from the group (such as gender, religion, etc.) } \\
\text { - In need of recognition or low self-esteem } \\
\text { - With a refusal to be manipulated and resistance to management direction } \\
\text { - With excessive commitment and zeal for the job } \\
\text { - High ability } \\
\text { - No support network in the work environment } \\
\text { - With professional incompetence } \\
\text { - In a period of personal crisis or with strong emotional reactions }\end{array}$ \\
\hline Predator & $\begin{array}{l}\text { - Emotional and social disorders } \\
\text { - Under the influence of subordinates or organizational culture } \\
\text { - Need to show the power } \\
\text { - Recognition through victims }\end{array}$ \\
\hline
\end{tabular}

\section{SYMPTOMS AND EFFECTS OF MOBBING}

\section{Evolving psychological destabilization}

Intense anxiety reduced tolerance to stress, intense discomfort, irritability/aggression, competition, loss of self-control, difficulty communicating, inability to externalize emotions, melancholy/depression, feelings of loneliness, feelings of loneliness, failure, impotence, frustration, resignation, feelings of guilt and/or shame, personality disorders, phobias, mania, substance abuse (tobacco, caffeine, alcohol), suicidal tendencies, post-traumatic stress disorder (Daliana N and Antoniou A-S, et al 2018)

\section{Physical symptoms}

Headaches/migraines, gastrointestinal disturbances, sleep disturbances, tachycardia, chest pains, menstrual disorders, hypotension/hypertension, profuse sweating, frequent urination, low upper and lower limb temperature, tremor-trembling, abdominal pain, indigestion, burning sensation, flatulence, nausea, vomiting, fainting spells, myalgia, cramps, muscle spasms, nervous twitching, itching, sexual mood disorders (Hirigoyen M-F 2002, Toukas D, et al 2012)

\section{Negative impact on the functioning of Organizations and Businesses}

Low-performance management, increased overtime, reduced quality standards, inability to meet deadlines, drop in employee morale, reduced customer satisfaction, increased need for closer supervision, deterioration of the organization's reputation, increased unjustified repeated absences, high employee turnover, poor customer service, increased employee turnover, increased number of accidents, inability to make the right decisions or prolong the process (Einarsen $\mathrm{S}$, et al 1994, 1998).

\section{MOBBING SYNDROME IN THE E.U}

Greece's occupancy exposure rates for 2010 are positioned somewhere around the middle of the 27 countries surveyed, with France, Belgium, and the Netherlands ranking at the top In the last places are Poland and Italy.

In Europe, national sources of information show gradual increases in violence and harassment over time. The incidence of physical violence is declining, while unfavorable social behavior is persisting. As a whole, $14 \%$ of employees reported that they had been subjected to violence or harassment in 2010. As violence takes many forms, it is sometimes hard to distinguish between them.

Papadeli (2015) incorporates in the conditions of "mobbing syndrome" the austerity policies implemented by the EU states in conditions of economic crisis through mass redundancies, availability, and labor mobility.

According to a European survey, women report more violence and harassment than men. Certain industries are more prone to experiencing the phenomenon: health and social work, transportation, tourism, and catering, and in general, in sectors with significant contact with third parties. Migrant workers and apprentices are more likely than contract workers and apprentices to encounter harassment and violence. The extent of the problem varies across Europe, with workers in Central 
European countries and Scandinavia reporting more violence and harassment than those in Southern Europe (Giacconi M and Di Nunzio D, 2015).

The European Parliament Resolution of 15 December 2011 on the mid-term review of the European strategy 2007-2012 on health and safety at work [2011/2147(INI)] deplores the lack of a common and uniform definition of harassment at the European level and calls on the Commission and the Member States to develop national strategies to combat violence at work that are effective and based on a common definition of harassment for all 27 Member States. (European Parliament,2011)

The European Agency for Safety and Health at Work states that "harassment at work is defined as repeated unjustified behavior towards a worker, or a group of workers, which causes risks to their health and safety".

"Health and safety hazards" include a risk to the mental and physical health of the worker (OSHA, 2002)

\section{LEGISLATIVE FRAMEWORK ON MOBBING}

Sweden was the first nation to legislate against bullying with the introduction of the Ordinance on Victimization at Work in 1993 (Ordinance on Victimization at Work, 1993)

The second country was France, adopting the Modernization of Employment Act of 17 January 2002

This was followed by other countries such as Belgium, Canada, and the United Kingdom

What is notable in the Swedish, French and Belgian legislation is the focus on the syndrome as an employer's problem

In Greece, only in 2021 was the Ratification of Convention 190 of the International Labour Organization for the elimination of violence and harassment at work Law 4808/2021 (Government Gazette 101 / A* 19.6.2021) followed by Ministerial

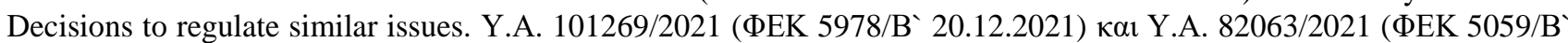
1.11.2021)

\section{MATERIAL AND METHOD}

\section{PURPOSE}

The purpose of the study is to record the respondents' views on the presence or not of psychological pressure/violence (mobbing) in the workplace of a sensitive sector, such as that of the hospital "Agios Dimitrios". The hypothesis of the paper aims to capture the rates of mobbing, based on the definition of the LIPT questionnaire and Leymann's criteria, to determine the causal factors, to highlight which groups are most vulnerable to mobbing, to describe how mobbing is expressed, and to document the ways of coping from the victims' perspective.

\section{The main research questions posed for the study of the above research problem are:}

- Is the "mobbing syndrome" perceived by the hospital's nursing staff "G.N.Th. Is it possible to detect the "Mental morbidity in the "St. Demetrius" mobbing unit?

- What factors are implicated in the occurrence of "mobbing syndrome" among the hospital's nursing staff "G.N.Th. St Demetrius'?

- Is there a lack of a legislative framework for the protection of the victim and the punishment of the perpetrator?

What are the proposals for dealing with the 'mobbing syndrome'?

\section{METHODS AND MATERIALS}

The Leymann Inventory of Psychological Terror" (LIPT) questionnaire (Appendix 1) was used to assess the data in this research study. The LIPT questionnaire is a widely used research tool for quantitative assessment of mobbing syndrome and has been used in several countries. The internal consistency index ranges from 79- 86 (Nielsen et al., 2010).

The survey was conducted at the Hospital "St. Demetrios General Hospital" to investigate the presence of the syndrome of moral harassment/psychological violence among the nursing staff of the hospital. Survey results were collected in $2018 / 2019$. 
To establish the existence of the syndrome, Leymann's criteria are set according to which it must be present:

- At least one mobbing behavior (one of the 45 harassment behaviors included in the LIPT questionnaire)

- At least once a week

- For more than six months

- All of the above within the last 12 months

In the research from the 190 questionnaires distributed, 109 were received, of which 91 were valid and 16 were invalid

\section{RESULTS}

Figure 1. Distribution of participants by status

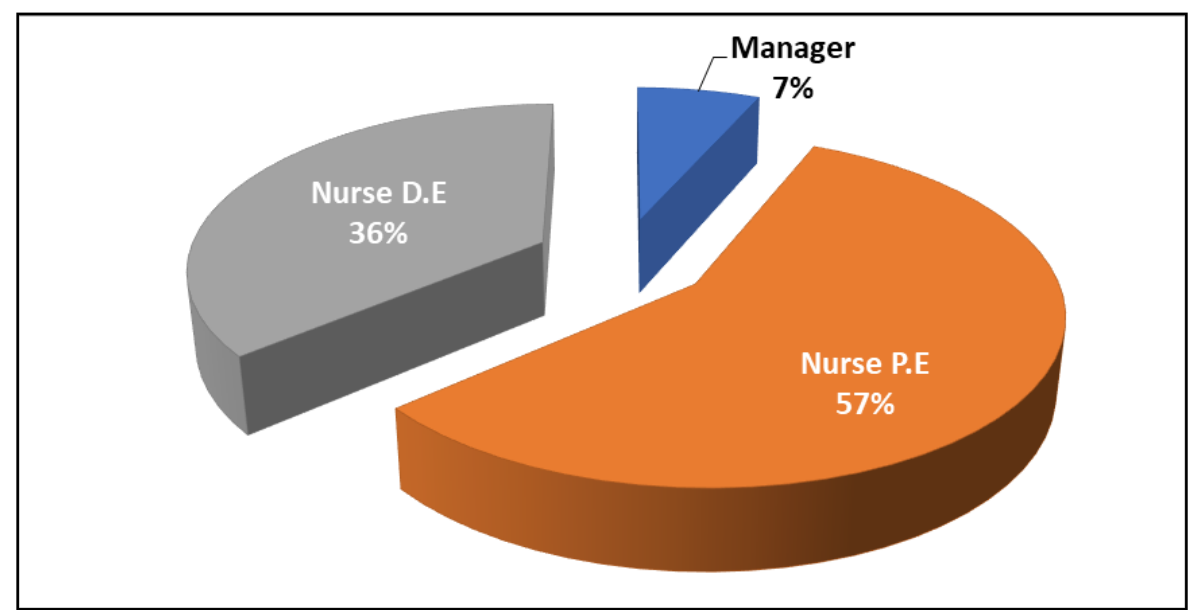

Figure 2. Distribution of participants by gender

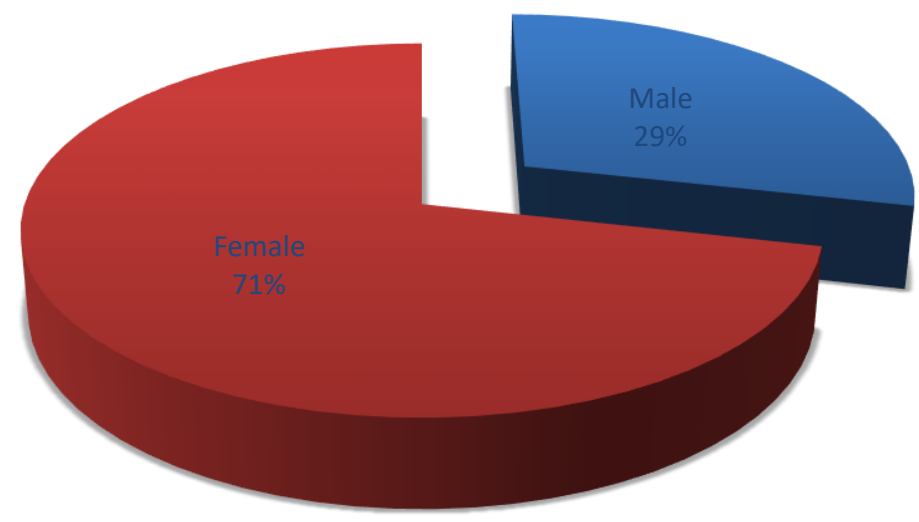


Figure 3. Distribution of participants by age

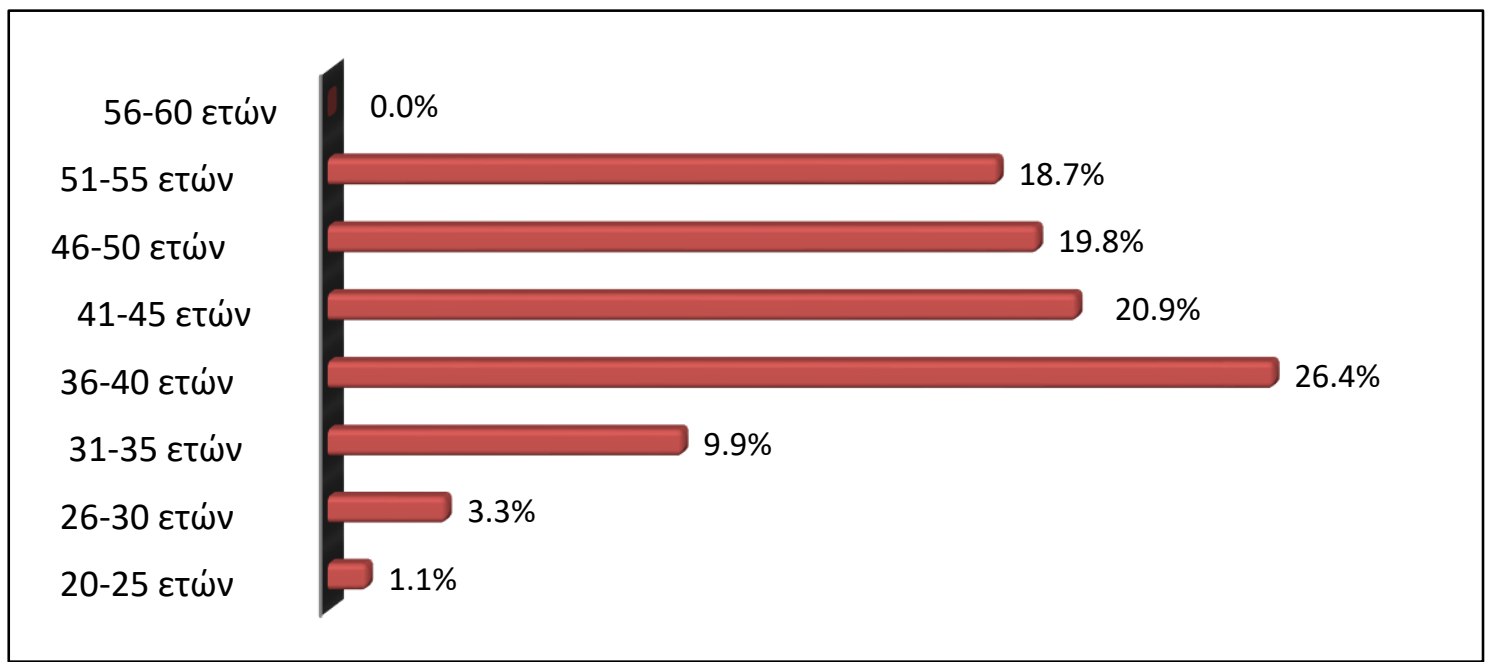

Figure 4. Distribution of participants by education
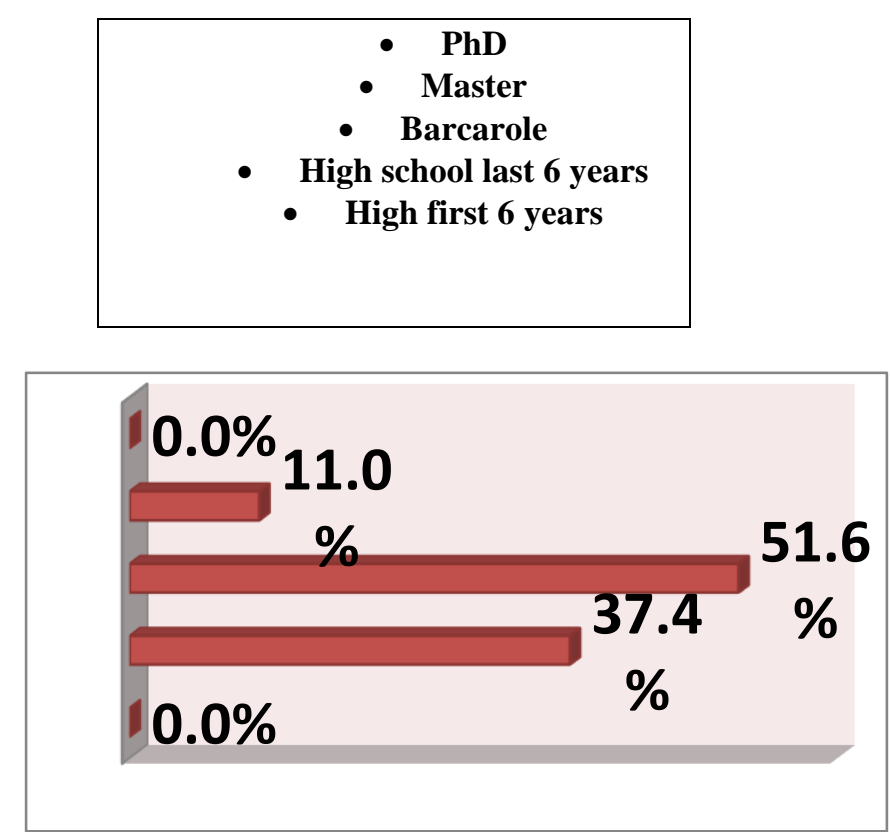
Figure 5. Distribution of participants according to marital status

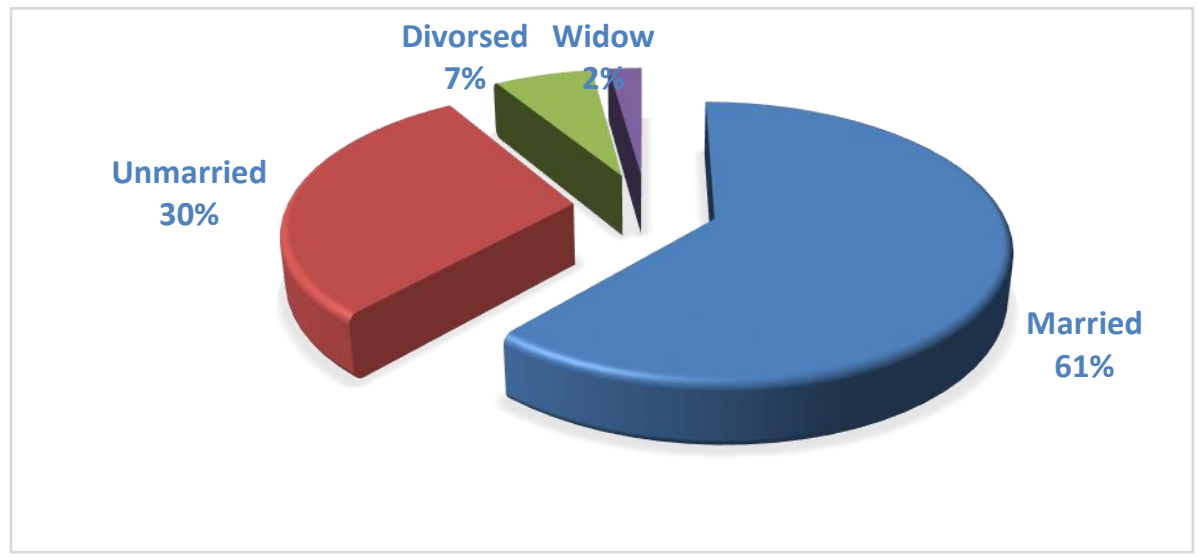

Figure 6. Distribution of participants according to the duration of work

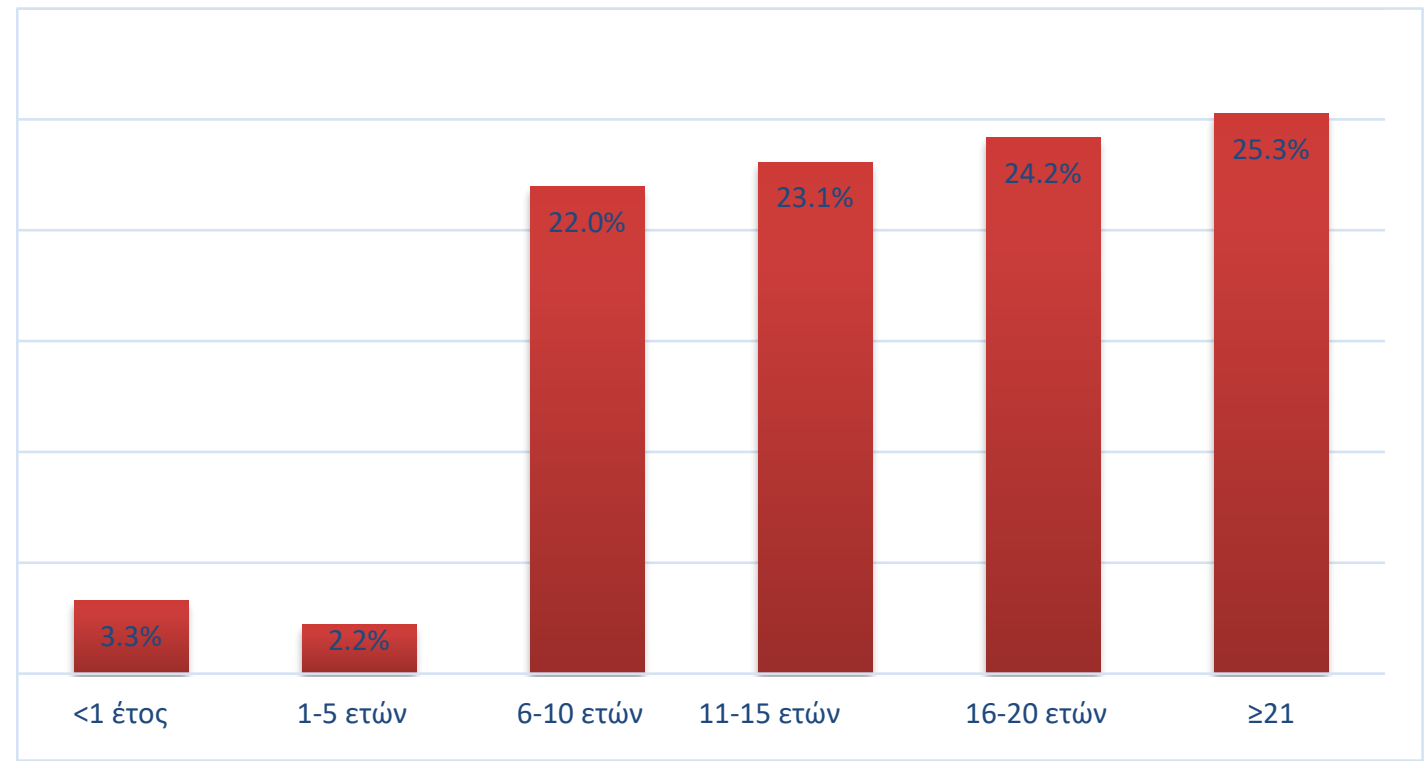


Table 1: Social isolation rates

\begin{tabular}{|l|c|}
\hline You are systematically isolated. & Relative frequency \\
\hline Your supervisor forbids you to express yourself & $6,6 \%$ \\
\hline You're interrupted when you speak & $13,2 \%$ \\
\hline Other people prevent you from expressing yourself & $15,4 \%$ \\
\hline Ways of exerting pressure & \\
\hline You're cursed, shouted at & $16,5 \%$ \\
\hline They criticize you negatively about your work & $16,5 \%$ \\
\hline They criticize you negatively about your personal life & $3,3 \%$ \\
\hline They harass you by phone & $2,2 \%$ \\
\hline You receive verbal threats & $8,8 \%$ \\
\hline You receive written threats & $1,1 \%$ \\
\hline Denial of contact by various means & $12,1 \%$ \\
\hline Receive looks of concern and gestures & \\
\hline They ignore your presence and only address others & $20,9 \%$ \\
\hline
\end{tabular}

Table 2: Social isolation rates

\begin{tabular}{|l|c|}
\hline You are systematically isolated. & Relatively frequency \\
\hline They do not address you & $13,2 \%$ \\
\hline They don't want you to go near them & $2,2 \%$ \\
\hline You have been placed in a job that isolates you from others & $3,3 \%$ \\
\hline They forbid your colleagues from talking to you & $0,0 \%$ \\
\hline They act like you don't exist & $13,2 \%$ \\
\hline They are addressed to you only in writing & $0,0 \%$ \\
\hline
\end{tabular}

Table 3: Threat of occupational status

\begin{tabular}{|l|c|}
\hline Your professional duties have been modified as a punishment & Relatively frequency \\
\hline You are not assigned any work, you have no duties & $0,0 \%$ \\
\hline You are assigned tasks without interest & $23,1 \%$ \\
\hline You are assigned tasks that are below your abilities & $15,4 \%$ \\
\hline You are constantly being given new tasks & $17,6 \%$ \\
\hline They assign you humiliating tasks & $11,0 \%$ \\
\hline You are assigned tasks far beyond your abilities & $3,3 \%$ \\
\hline
\end{tabular}


Figure 7. Job modification chart

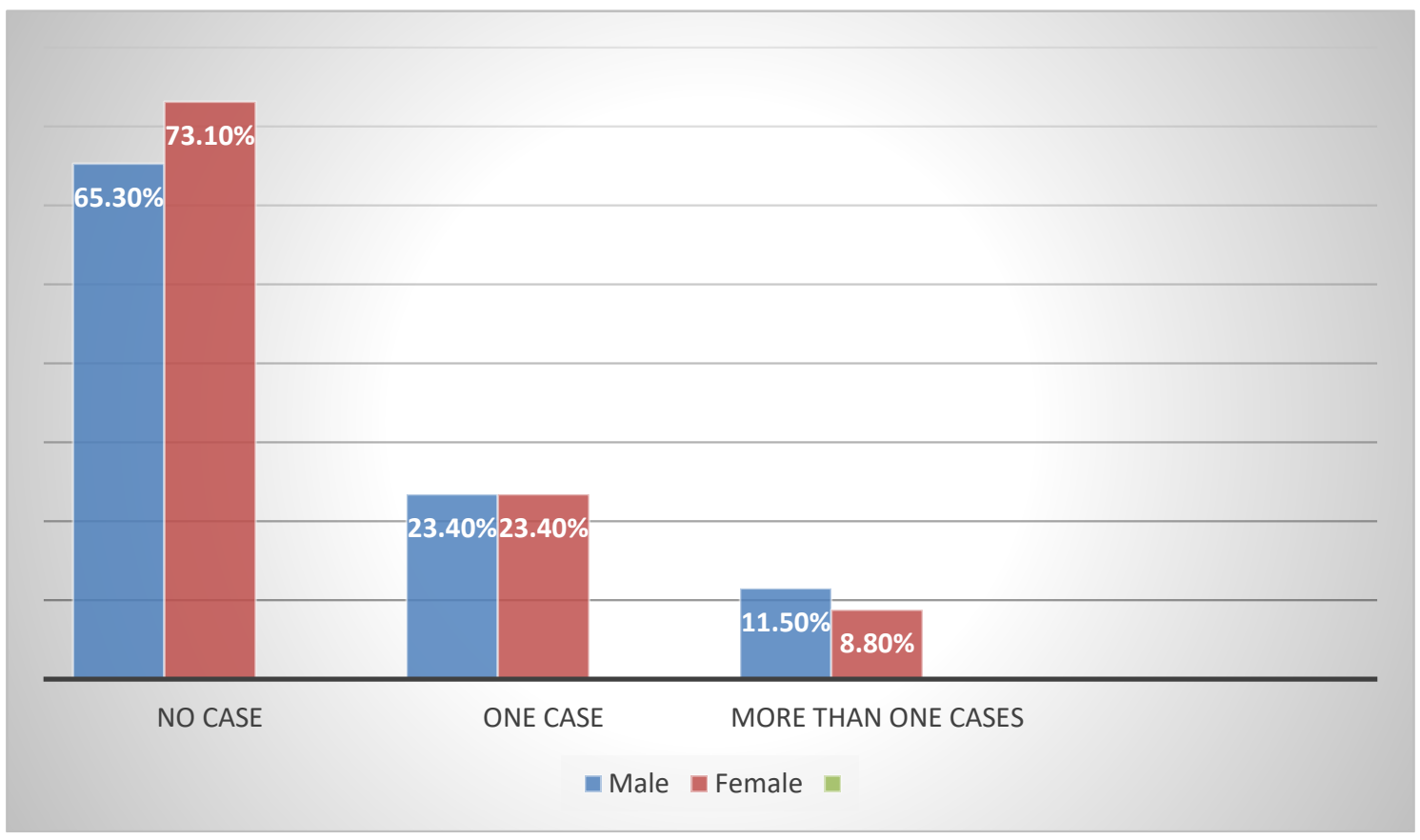

Table 4: Attacks on the face of the victims

\begin{tabular}{|l|c|}
\hline Attacks on your face & Relatively frequency \\
\hline They talk badly behind your back & $31,2 \%$ \\
\hline Spreading false news about you & $8,8 \%$ \\
\hline They ridiculed you in front of others & $2,2 \%$ \\
\hline They imply that you are mentally ill & $4,4 \%$ \\
\hline $\begin{array}{l}\text { They want to force you to undergo a psychiatric } \\
\text { examination. }\end{array}$ & $0,0 \%$ \\
\hline They make fun of you for your disability & $3,3 \%$ \\
\hline They mimic your appearance and gestures to ridicule you & $4,4 \%$ \\
\hline Attack your religious and political beliefs & $5,5 \%$ \\
\hline They insult your origins & $3,3 \%$ \\
\hline $\begin{array}{l}\text { You are obliged to write writings that damage your } \\
\text { conscience }\end{array}$ & $12,1 \%$ \\
\hline your work is being judged unfairly. & $2,2 \%$ \\
\hline insult you by using obscene and sophisticated terms & $2,2 \%$ \\
\hline you are subjected to sexual innuendo or sexual acts & $0.0 \%$ \\
\hline They question your decisions. & $7,7 \%$ \\
\hline
\end{tabular}

The number of health professionals who said they had been subjected to at least one mobbing behavior that affected their social image, work practice, and professional status was $41.7 \%$. 
Figure 8. Frequency, duration, and forms of moral harassment/psychological violence of health professionals in their workplace

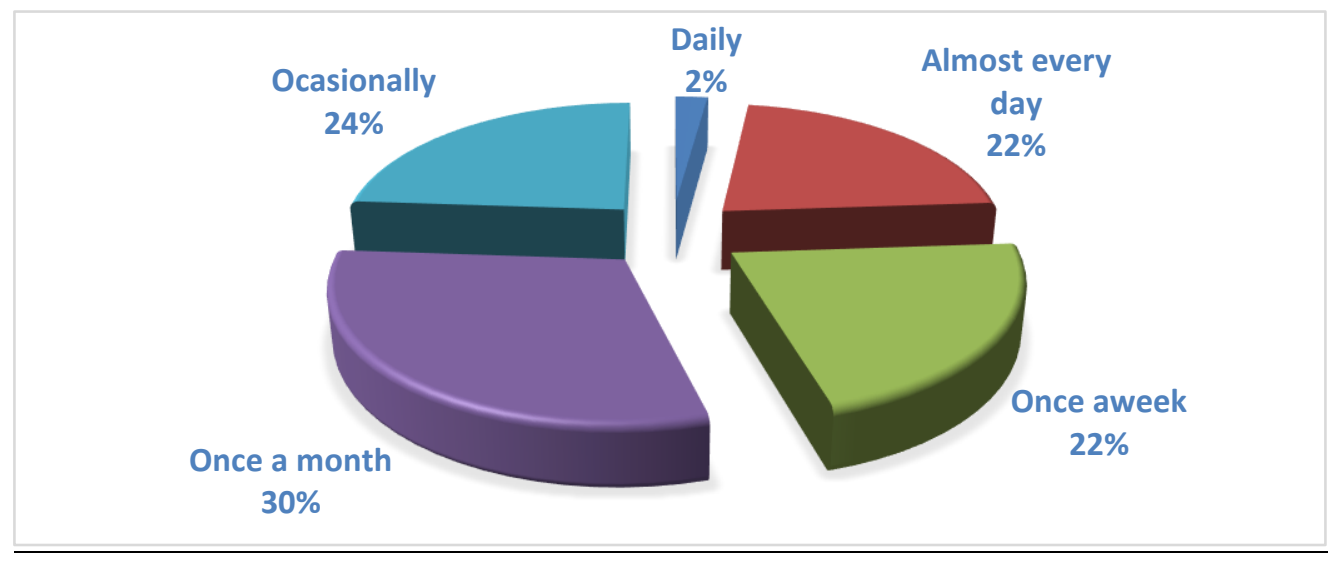

Figure 9. Duration of mobbing behaviors

Are you still dealing with mobbing situations today?

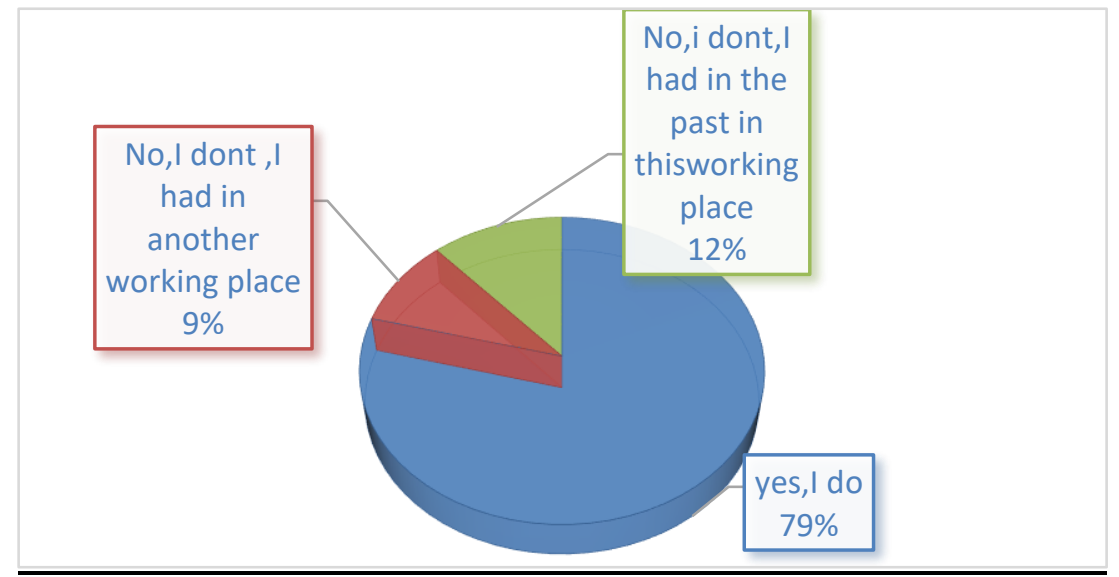




\section{Figure 10. Characteristics of victims of mobbing}

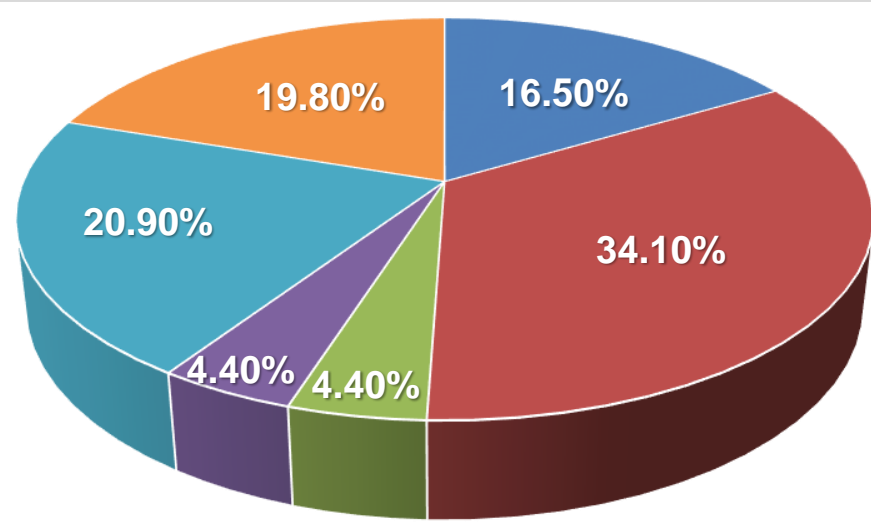

- Coworker

- Manager or Superior to you

- Subsistent to you

- Males

- Females

- Males and females

Table 5: Where victims turned for support

\begin{tabular}{|l|c|}
\hline Have you talked to anyone about your working problems? & Relatively frequency \\
\hline Coworker & $29,7 \%$ \\
\hline Supervisor & $11,0 \%$ \\
\hline Personnel manager & $3.3 \%$ \\
\hline Staff representative & $1,1 \%$ \\
\hline Labor inspector & $0.0 \%$ \\
\hline Doctor of work & $2,2 \%$ \\
\hline Another specialty doctor & $0,0 \%$ \\
\hline Social worker, psychologist & $7,7 \%$ \\
\hline Friend out of the working place & $26,4 \%$ \\
\hline Family, relatives & $28,6 \%$ \\
\hline No, I don't have anyone to talk but I want to & $6,6 \%$ \\
\hline No, I don't have anyone to talk and I don't want to & $4,4 \%$ \\
\hline
\end{tabular}


Table 6: Behavioral attributions

\begin{tabular}{|l|c|}
\hline To which you attribute hostile behavior & Relative frequency \\
\hline The bad overall atmosphere at work & $13,2 \%$ \\
\hline The bad organization of work & $7,5 \%$ \\
\hline Problems in the working management & $34,1 \%$ \\
\hline Problems in the competition between co-workers & $11,0 \%$ \\
\hline In jealousy & $7,7 \%$ \\
\hline In working conflicts & $8,8 \%$ \\
\hline Because they want you to stop working there & $2,2 \%$ \\
\hline Because I am different from the others (origin, nationality, gender, etc) & $0,0 \%$ \\
\hline I don't know & $2,2 \%$ \\
\hline
\end{tabular}

Figure 11. Percentage of perception of mobbing behaviors in others

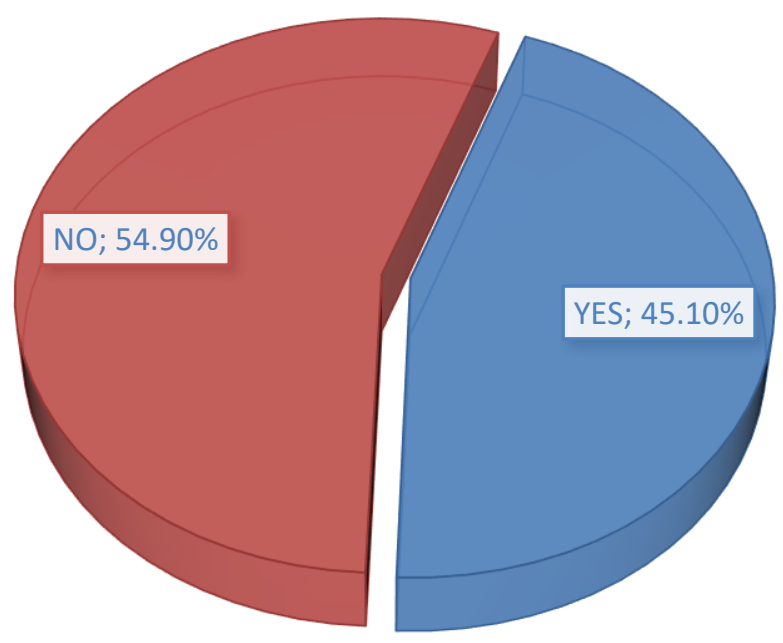




\section{DISCUSSIONS}

The hypothesis in this study was confirmed, since the present study shows that 1.6 out of ten health professionals experienced in their workplace, according to Leymann's definition and criteria (at least one behavior, at least once a week, and for at least six months, within the last twelve months) In particular, the largest proportion (79\%) of health professionals who said they had been exposed to one or more mobbing behaviors continue to experience them today. $12 \%$ said they had previously encountered them in another job, while 9\% said they had previously encountered them in the workplace where the survey was conducted. The rates in this survey for recording "mobbing syndrome" are $16.48 \%$, and it is not possible to compare this with another survey from earlier years in the same hospital.

Across gender, marital status, years of specialized experience, and educational level, aggressive attitudes toward victims seem not to differ significantly. The behavior of mobbing leads to the social isolation of health professionals by ignoring them as individuals by $25 \%$.

Behaviors that mob by modifying professional responsibilities to assign tasks not related to their interests and below their potential, by $40 \%$

In the health field, $41.7 \%$ of those who have experienced mobbing described it as affecting their social image, their work practice, and their professional status.

The victims turned to colleagues for support $30 \%$, friends and family $60 \%$, and no one in the administration. In the workplace, in management, and in poor work organizations, employees take the most responsibility.

The results seem to agree with similar surveys in Greece as reported by Karatza (2016) 30\% of employees in the hospitals of the 1st Regional Health Service of Attica, responded that they had been bullied at work. Chondropoulou, (2017) in a study of Greek data on the public sector describes that the rates of "mobbing" are increased in the fields of health and education Respectively in a Cypriot study to identify the phenomenon of "mobbing" in employees in the Primary Health Care of the country, where the LIPT questionnaire was used, "mobbing" behaviors came from people at the top of the hierarchy, such as bosses in $55.9 \%$ and people of the same professional rank in $50 \%$, the vast majority of whom were women $(83.8 \%)$ Victims attribute "mobbing" mainly in poor work organization (43.3\%) and then in management problems in $40 \%$ (Chira, 2014).

The economic crisis across the EU has exacerbated "mobbing" attitudes. possibility of violence and harassment at work. Deteriorating working conditions, such as higher workloads, higher psychological and physical demands on work, greater job insecurity, workplace conflicts, and poor management practices, create a greater likelihood of violence and harassment at work. (Giacconi M and Di Nunzio D, 2015).

\section{CONCLUSIONS}

As a dynamic phenomenon, mobbing evolves as a hostile work climate develops, is manifested as a source of work stress, and affects the mental and physical health of employees. Psychopathology and physical illnesses are associated with work stress, which is a function of time and intensity.

In addition to negatively impacting the health and productivity of workers, violence and harassment at work undermine social networks and the sustainability of work.

Workers are more likely to experience labor violence, harassment, and conflicts at work during economic crises and insecurity when unemployment and job insecurity increase. In an environment of uncertainty, survival of the fittest ideology, and in the absence of cohesiveness and solidarity, they appear.

The cornerstone to preventing "mobbing syndrome" are employee participation, the right rewards, and the positive of the organizational climate.

We conclude that its rapid spread is a function of socio-economic developments or structural characteristics of the working environment and less personal desires, and individual characteristics of the perpetrator and the victim.

Conducting more and more surveys in different workplaces, firstly, makes the phenomenon of mobbing itself more known, raising awareness among all employees and organizations, and secondly, it can act as a lever to pressure legislators for the establishment of a legal framework on this issue. After all, it is a well-known fact that laws usually follow phenomena. Awareness of the 'mobbing syndrome' in the workplace could be the starting point for its reduction and prevention.

While it is necessary to create legislation to deal with labor violence and harassment, such legislation will not eliminate mobbing if policies exist to support its causes and increase social inequalities. 


\section{REFERENCES}

1. Leymann H. (1990), Mobbing and Phycological terror at workplaces. Violence and Victims, 1990 Springer Publishing Company. 5, 2.

2. Leymann H. (1996), "The content and development of mobbing at work", European Journal of Work and Organizational Psychology, 5,165-184.

3. Duffy M, Sperry L. (2007) Workplace mobbing: Individual and family health consequences. The Family Journal, $15,398-404$.

4. Chappell D\& Di Martino V. (2001) Global Workplace Violence. Geneva: International Labour Office. ISBN 92-2117948-6 / 978-92-2-117948-1. Chichester: Wiley.

5. Olweus D.N(1993), Bullying at school: what we know and what we can do, Oxford: Blackwell., 40-41.

6. Brodsky C. (1976). The harassed worker. Toronto, Ontario, Canada: Lexington Books, DC Health, 42-48.

7. Zapf D. and Gross C. (2001) Conflict escalation and coping with workplace bullying: A replication and extension. European Journal of Workplace and Organizational Psychology 10, 497-522.

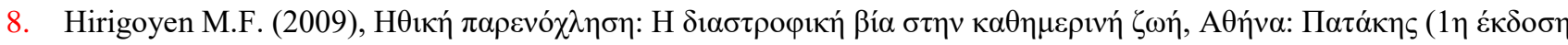
2000).

9. Hirigoyen, M.F. (2012) Le Harcèlement Moral. La violence perverse au quotidian. Available at: http://newsoftomorrow.org/vie/psycho/m-f-hirigoyen-le-harcelement-moral-la-violence-perverse-au-quotidien. Accessed at :10/11/17

10. Keashly L. and Jagatic K. (2003). By any other name American perspectives on workplace bullying, in Einarsen S., Hoel H., Zapf D., and Cooper C.L. (eds.), Bullying and emotional abuse in the workplace: International perspectives in research and practice, London: Taylor Francis. 31-61.

11. Vartia M. (1993). Psychological harassment (bullying, mobbing) at work. In Kauppinen-Toropainen (eds.), OECD panel group on women, work and health. Helsinki-Finland.: Ministry of Social Affairs and Health,149-152.

12. Vartia M. (2003) Workplace bullying - a study on the work environment, well-being, and health. Faculty of Arts, University of Helsinki, Helsinki 2003.2 Available http://ethesis.helsinki.fi/julkaisut/hum/psyko/vk/vartiavaananen/workplac.pdf Accessed at:10/11/2017.

13. Andersson J. (2001). Report on harassment at work. 2001/2339 (INI). Committee on Employment and Social Affairs of the Puropean Parliament. http://www.europarl.europa.eu/sides/getDoc.do?pubRef=//EP//NONSGML+REPORT+A5- 2001-0283+0+ $\mathrm{DOC}+\mathrm{PDF}+\mathrm{V} 0 / / \mathrm{EL}$

14. Tepper B. J. (2000), Consequences of abusive supervision, Academy of Management Journal, 43(2), 178-190

15. Aquino K. (2000) Structural and individual determinants of workplace victimization: Hierarchical status and conflict management style effects. Journal of Management. 26,171-193.

16. Aquino K. and Thau S. (2009). Workplace victimization: Aggression from the target's Perspective", Annual Review of Psychology, 60, 717-741.

17. Notelaers G. (2010), "Workplace bullying: A risk control perspective”, Ph.D. Thesis, University of Bergen

18. Ferrari E. (2004), "Raising awareness on women victims of mobbing, The Italian contribution", Daphne program, European Commission

19. Khoo, S.B. (2010). Academic mobbing: Hidden health hazard at the workplace. Malaysian Family Physician, 5(2), 61-67.

20. Ege, H. (2007). Il Fenomeno del Mobbing: Prevenzione, Strategie, Soluzioni. Available at: https://www.personaedanno.it/mobbing-discriminazioni-molestie/il-fenomeno-del-mobbing-prevenzione-strategiesoluzioni-harald-ege. Accessed at :10/11/17

21. Sahin B. et al (2012). «Assessment of Turkish junior male physicians' exposure to mobbing behavior. Croatian Medical Journal 
22. Daliana N . and Antoniou A-S(2018) Depression and suicidality as results of workplace bullying Dialogues in Clinical Neuroscience \& Mental Health, 1(2),50-56.

23. Hirigoyen M-F. (2002)Ethical Harassment in the working place, publications Pataki, Athens 350.

24. Toukas D, Delichas, M., \& Karageorgiou, A. (2012) Conceptual definitions and causal factors of psychological violence at work. Their role in assessing the risk of mobbing, Archives of Greek Medicine.29(2),162-173.

25. Einarsen S, Raknes B I ,Matthiesen SB (1994). Bullying and harassment at work and their relations to working environment quality. An exploratory study. The European Work and Organizational Psychology, 4,381-401.

26. Einarsen, S, Skogstad A,Matthiesen SB (1998). Bullying, burnout, and well-being among assistant nurses. Journal of Occupational Health and Safety Australia and New Zealand, 14, 563-568.

27. Papadeli Ch. (2017) The burnout of Secondary Education teachers of the first availability of the Ministry of Education in the context of reform in a crisis environment: a study of attitudes, views, embodied problems and emotional disorders. Doctoral dissertation, University of Peloponnese, Corinth

28. Giacconi M and Di Nunzio D (2015). Violence and harassment in European workplaces: Extent, impacts, and policies. Eurofound

\section{9. https://www.eurofound.europa.eu/country/greece}

30. Ordinance of the Swedish National Board of Occupational Safety and Health containing Provisions on measures against Victimization at Work (Arbetarskyddsstyrelsens författningssamling [AFS] 1993:17) (Swed.)

31. European Parliament(2011). Essay according to harassment in the working environment(2001/2339 INI)

32. OSHA European Organization for Security and Health at work. (2002)Harassment in the workplace. Press of Technical

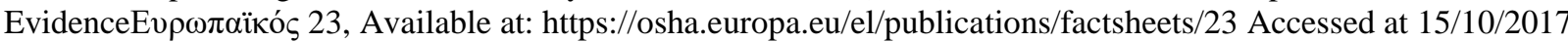

33. Nielsen M. et al (2010) The impact of methodological moderators on prevalence rates of workplace bullying. A metaanalysis. Journal of Occupational and Organizational Psychology,83, 955-979

34. Karatza et al. (2016) Workplace bullying and general health status among the nursing staff of Greek public hospitals. Annals of General Psychiatry, 15.

35. Chondropoulou E. (2017), The moral and psychological harassment (mobbing) of civil servants. Master's thesis, University of Macedonia Thessaloniki.

36. Chira S. (2014). Assessment of the presence of mobbing syndrome among health professionals working in primary health care in Cyprus. Master Thesis, Open University of Cyprus, Nicosia. 